\title{
Landscape Studies of Maintenance of Lawns in some Football Yards at Dakahlia Governorate \\ Part 1. Effect of Different Fertilization Programs on the Growth Characteristics and Chemical Composition of Turfgrasses of Five Established Football Fields. \\ AbdelKader, H. H. ${ }^{1}$; A. A. Hegazy ${ }^{1}$; Sawsan S. Sayed ${ }^{2}$ and Amira I. Abdellatif ${ }^{1}$ \\ ${ }^{1}$ Vegetable and Floriculture Departrment, Mansoura University, Mansoura, Egypt \\ ${ }^{2}$ Horticulture Research Institute, Agriculture Research Center, Cairo, Egypt
}

ABSTRACT

This study was carried out during the two successive seasons of 2013/2014 and 2014/2015 on five established football (soccer) green fields (yards) in the urban and suburban areas of Mansoura City, Dkahlia Governorate, Egypt. It aimed to compare the effects of different fertilization programs on the performance and quality of the lawn (turfgrass) of the five yards (fields). Five football fields were chosen based on similarity of basic specifications namely; a standard field size (65-70 m in width and 100$110 \mathrm{~m}$ in length), planted using sods of Paspalum vaginatum Sw lawn (turfgrass), sandy soil (sand thickness of $15-20 \mathrm{~cm}$ over 30 $\mathrm{cm}$ layer of pebble stones), all have existing drainage systems, and no soil aeration were carried out in any of the fields' maintenance programs. The football yards (fields) were Mansoura Stadium, Mansoura University and El-Shaab stadiums (located in Mansoura city) in addition to Beny Ebeid and Secondary Beny Ebeid stadiums (located in Beny Ebeid town). Data of maintenance programs were collected from the maintenance managers of different stadiums. In addition, measurements for the visual color and quality in addition to total chlorophyll contents ( $\mathrm{mg} / \mathrm{g}$ fresh clipping sample), and $\mathrm{N}, \mathrm{P}$ and $\mathrm{K}$ percentages in the clipping samples of the turfgrass (lawn) of the five fields were carried out during the two seasons. The obtained results showed that increasing number of $\mathrm{N}$ applications (doses) combined with reasonable low quantity each application (dose) had a positive effect on color and quality of the turf in addition to its chlorophyll content. The results also supported the need of adding phosphorus to the turfgrass, but to a much lesser degree than the need of nitrogen. Based on the results of both seasons, Mansoura University Stadium fertilization program was the best to achieve better visual color and quality of the turfgrass in addition to total chlorophyll contents ( $\mathrm{mg} / \mathrm{g}$ fresh weight) of the clippings. This program comprised of five applications (doses) of a mixture of urea and potassium nitrate fertilizers ( $50 \%$ each); each dose containing $0.62 \mathrm{Kg} \mathrm{N} / 100 \mathrm{~m} 2$ of the grass field during spring and summer months (March - October); summing up a total of $3.12 \mathrm{Kg} \mathrm{N} / 100 \mathrm{~m} 2$ / year, in addition to two applications of calcium super phosphate; each containing $0.34 \mathrm{Kg} \mathrm{P} / 100 \mathrm{~m} 2$ of the grass field during fall and winter months (November February) summing up a total of $0.69 \mathrm{Kg} \mathrm{P} / 100 \mathrm{~m} 2$ of grass.

\section{INTRODUCTION}

Turfgrasses (lawns) are used in the landscape and occupy a large area of any garden and park and used extensively to provide places for recreation and sport. Turfgrasses provide a playing surface that is safe for athletes at low cost. Fields with good quality turfgrass reduce the probability of injury in contact sports. In addition, a surface temperature between 7:00 am and 7:00 pm during June of 2002 at Brigham Young University of the synthetic field recorded an average of $117{ }^{\circ} \mathrm{F}$ which increases the injury risk for players, while the natural grass surface recorded an average of $78^{\circ} \mathrm{F}$ only (Villwock et al., 2009).

Extensive use, improper construction and/or poor management would result in poor quality of the field, and this would result in negative effect on activities and to affect the safety of the participants. (Cockerham et al., 2004). A well- established and maintained sport fields can tolerate the extensive use of the field.

Paspalum (Paspalum vaginatum Sw.), Fam. Poaceae, also known as Bahia grass, is a tall perennial American grass that grows extensively in subtropical and tropical regions. It is a warm-season turfgrass and one of the major turfgrasses all-over the world. It has s a long growing season and has a strength of the coarse nature of the creeping (runners) growth with bluish green color and an attractive appearance. This turfgrass is used in parks, gardens, golf courses, athletic field, and for recreation and landscape purposes.

Proper management of cultural requirements for natural sports fields will ensure acceptable playing surfaces for athletes. These cultural requirements include fertilization, irrigation, mowing, after-game restoration, and controlling the use of the field in addition to controlling weeds, pests and diseases when it is necessary.
Quality turfgrasses are produced when a balance is undertaken between nutrients availability and mowing which tend to reduce turfgrass leaf area available for producing necessary plant metabolites. The use of proper fertilization would produce a vigorous, dense turfgrasses.

The proper use of nitrogen, phosphorus, and potassium is the backbone of any fertiliion program (Taiz, 2002). The effect of $\mathrm{N}$ fertilization on turfgrass has been researched extensively (Beard,1973). Turner and Hummel (1992) reported that nitrogen significantly affect turfgrass growth of shoots and roots, density, color, and stress tolerance.

In turfgrasses, phosphorus shortens the establishment stage and causes the production of vigorous root system, which improve tolerance of the turfgrass to cold, heat, and drought tolerance and recovery, improves water use efficiency; and suppress some turfgrass diseases (Carrow et al., 2001).

A comprehensive study was carried out to investigate effects of different maintenance programs of lawns (turfgrass) in some football (soccer) fields at Dakahlia Governorate. This paper represents a study of the effect of different nitrogen and phosphorus fertilization programs on color and quality of the five football fields.

\section{MATERIALS AND METHODS}

This study was carried out in the urban and suburban areas of Mansoura city, Dkahlia Governorate, Egypt during the two successive seasons of 2013/2014 and 2014/2015. The study aimed to investigate the effects of different maintenance programs on the performance and quality of the turfgrass of five established football (soccer) green fields. 
Locations and description of fields:

Football fields were chosen to carry on this investigation because they all share similar basic specifications. Three fields are located in Mansoura city (Mansoura city, university of Mansoura and El-Shaab stadiums) and two in Beny Ebeid town (Beny Ebeid and secondary Beny Ebeid stadiums).

The five fields shared the following basic specifications:

1. Size: Standard field size $65-70 \mathrm{~m}$ in width and $100-$

$110 \mathrm{~m}$ in length.

2. Soil preparation type and thickness: $15-20 \mathrm{~cm}$ sand over $30 \mathrm{~cm}$ layer of pebble stones.

3. Turfgrass species: Paspalum vaginatum Sw.

4. Turfgrass planting method: Sods.

5. An existing drainage system

6. No rolling or soil aeration were carried out in any of the fields' maintenance programs.
Table 1. Monthly means for temperature and relative humidity recorded from $1^{\text {st }}$ of July 2013 till the end of June 2015.

July2013 at June $2014 \quad$ July2014 at June 2015

\begin{tabular}{lccccc}
\hline Data & $\begin{array}{c}\text { mean } \\
\mathbf{T a o}^{\circ} \mathbf{c}\end{array}$ & $\begin{array}{c}\text { Mean } \\
\text { Rho\% }\end{array}$ & Data & \multicolumn{3}{c}{$\begin{array}{c}\text { mean } \\
\mathbf{T a o}^{\circ} \mathbf{c}\end{array}$} & $\begin{array}{c}\text { Mho\% } \\
\text { Rho }\end{array}$ \\
\hline $01 / 07 / 2013$ & 29.8 & 76.5 & $01 / 07 / 2014$ & 29.8 & 67.6 \\
$01 / 08 / 2013$ & 29 & 74.8 & $01 / 08 / 2014$ & 29.6 & 70.1 \\
$01 / 09 / 2013$ & 28.1 & 71 & $01 / 09 / 2014$ & 28.9 & 65.4 \\
$01 / 10 / 2013$ & 22.9 & 76.1 & $01 / 10 / 2014$ & 23.7 & 60.2 \\
$01 / 11 / 2013$ & 19.2 & 66.4 & $01 / 11 / 2014$ & 22.2 & 65.4 \\
$01 / 12 / 2013$ & 16.3 & 68.1 & $01 / 12 / 2014$ & 15.8 & 70.8 \\
$01 / 01 / 2014$ & 13.9 & 73.4 & $01 / 01 / 2015$ & 15.1 & 81.3 \\
$01 / 02 / 2014$ & 13.9 & 73.6 & $01 / 02 / 2015$ & 14.8 & 81.1 \\
$01 / 03 / 2014$ & 16.7 & 75.1 & $01 / 03 / 2015$ & 17 & 71.8 \\
$01 / 04 / 2014$ & 18.4 & 70 & $01 / 04 / 2015$ & 20 & 70.8 \\
$01 / 05 / 2014$ & 23 & 68.8 & $01 / 05 / 2015$ & 23.6 & 68 \\
$01 / 06 / 2014$ & 24.8 & 71.2 & $01 / 06 / 2015$ & 25.7 & 69.6 \\
\hline
\end{tabular}

Table 2. Physical and chemical properties of five fields according to the method of Jackson (1960).

\begin{tabular}{|c|c|c|c|c|c|c|}
\hline Soil sample & & Beny Ebeid & $2^{\text {IId }}$ Beny Ebeid & Mansoura University & Mansoura & El-Shaab \\
\hline \multirow{5}{*}{$\begin{array}{l}\text { Mechanical } \\
\text { analysis } \%\end{array}$} & c. sand & 2.16 & 2.47 & 3.58 & 4.57 & 3.18 \\
\hline & f. sand & 19.81 & 20.14 & 29.41 & 33.7 & 31.80 \\
\hline & Silt & 26.94 & 29.41 & 40.38 & 43.41 & 39.95 \\
\hline & Clay & 51.09 & 47.98 & 26.63 & 18.32 & 25.07 \\
\hline & T.class & Clay & Clay & sandy clay loam & Sandy loam & sandy clay loam \\
\hline \multirow{3}{*}{$\%$} & SP & 68.5 & 65.3 & 52.9 & 48.32 & 53.7 \\
\hline & $\mathrm{OM}$ & 1.94 & 1.86 & 1.56 & 1.29 & 1.55 \\
\hline & $\mathrm{CaCo}{ }_{3}$ & 4.65 & 4.22 & 5.53 & 5.81 & 5.09 \\
\hline \multicolumn{2}{|c|}{ E.C. $\left(\mathrm{dS}, \boldsymbol{m}^{-1}\right) 1: 5$} & 1.13 & 1.05 & 0.82 & 0.71 & 0.93 \\
\hline \multirow{4}{*}{$\begin{array}{l}\text { PH1:2.5 } \\
\text { Available } \\
\text { mg.kg }\end{array}$} & & 7.65 & 7.88 & 8.13 & 8.18 & 8.09 \\
\hline & $\mathrm{N}$ & 59.7 & 58.3 & 49.5 & 48.4 & 51.4 \\
\hline & $\mathrm{P}$ & 7.13 & 7.05 & 6.13 & 5.72 & 6.65 \\
\hline & $\mathrm{K}$ & 289.3 & 271.9 & 230.4 & 221.6 & 244.8 \\
\hline \multirow{4}{*}{$\begin{array}{l}\text { DTPA exter. } \\
\text { mg.kg-1 }\end{array}$} & $\mathrm{Fe}$ & 3.62 & 3.53 & 2.80 & 2.71 & 2.97 \\
\hline & $\mathrm{Zn}$ & 1.43 & 1.29 & 0.87 & 0.78 & 0.98 \\
\hline & $\mathrm{Mn}$ & 2.10 & 1.95 & 1.66 & 1.53 & 1.78 \\
\hline & $\mathrm{Cu}$ & 0.32 & 0.25 & 0.09 & 0.07 & 0.14 \\
\hline
\end{tabular}

Metrological data:

\section{Fertilization programs:}

Data were obtained from the stadium management questionnaire on fertilizer forms and quantities. Phosphorus was applied as calcium super phosphate during winter period to the five fields in two or three equal quantities. Nitrogen fertilization was applied during spring period to the five fields in two or three equal quantities of fertilization and three equal quantities of fertilization during summer period. Nitrogen source was potassium nitrate to four fields, while a mixture of urea and potassium nitrate 50:50 were used for Mansoura University field.

Phosphorus and Nitrogen were calculated as follows:

Nitrogen or Phosphorus applied to every $100 \mathrm{~m}^{2}$

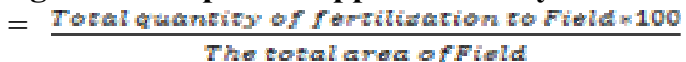

Nitrogen the amount of potassium nitrate $=$

$$
\text { add to } 100 \mathrm{~m}^{2} * \frac{33.5}{100}
$$

Nitrogen the amount of urea $=$ add to $100 \mathrm{~m}^{2} * \frac{46}{100}$

Phosphorus the amount of super phosphorus $=$

\section{Measurements:}

$$
\text { add to } 100 \mathrm{~m}^{2} * \frac{15.5 \text { or } 12.5}{100}
$$

A. Turf color: was visually evaluated and was scored on a scale of 1-9 (where, 8-9= dark green, 6-7=green, 5$6=$ yellowish green, 3-4=greenish yellow, and 1$2=$ yellow or brown).
B. Turf quality: turf quality was visually scored according to Alshammary et al., (2004) on a scale of 1-9, based on density, uniformity and color, where $8-9=$ excellent ideal green, dense, and uniform turf, $6-7=$ good, $4-5=$ acceptable, $3-4=$ bad, and $1-2=$ very bad or completely dead or dormant brown/yellowish colored turf. Any value below four was considered as unacceptable quality.

C. Chemical analysis:

1- Photosynthetic pigments:

Total chlorophyll, A, and B were determined in turf clippings according to the method of Machinney (1941).

2- NPK contents of the clippings:

The N, P and $\mathrm{K}$ percentages in dry matter of clippings were recorded in both seasons. The samples of grass clippings were dried at 70 until constant weight, grounded and wet digested using Sulphuric and Perchloric acids. Nitrogen percentages was determined according to the method of Kockand McMeekin (1962). Phosphorus percentages were determined according to method of Murphy and Riley (1962) and Potassium percentages was determined according to (Wilde et al., 1985).

\section{Statistical analysis:}

Major elements and chlorophyll contents were analyzed as a simple experiment (one factor) in a complete randomized block design with (5) fields each treatment contains three replicates with a total of 15 values, while other data were factorial experiment (two factor (3 seasons 
$X_{5}$ fields) in a Complete Randomized Block Design with three replicates with a total of 45 Values.

Analysis of Variance (ANOVA) of the data of was carried out using Statistical Analysis System (SAS). The Least Significant Difference (L.S.D.) method at significance level of 5\% (Gomez and Gomez, 1984) was used to compare differences between means.

\section{RESULTS AND DISCUSSION}

\section{Results}

Table (3) showed amount of nitrogen quantity applied during spring and summer periods in addition to amount of phosphorus quantity applied during winter period to different fields. As for nitrogen quantity, it is obvious that, in the first season, each of Beny Ebied fields received five doses and high quantity of nitrogen during summer and spring period (Quantity 4.84 and dose $0.97 \mathrm{Kg} / 100 \mathrm{~m}^{2}$ ). In the same season, El- Shaab field received five doses and high nitrogen quantity (Quantity 4.50 and dose 0.90 $\mathrm{Kg} / 100 \mathrm{~m}^{2}$ ) nitrogen quantity during each of summer and spring growth periods, and, thus received less nitrogen quantity than both Beny Ebeid fields. In addition, Mansoura University field received medium amounts of nitrogen quantity using five doses (Quantity 3.12 and dose 0.62 $\mathrm{Kg} / 100 \mathrm{~m}^{2}$ ) during summer and spring, while Mansoura field received three doses and the lowest amounts of nitrogen quantity among all fields during both growth periods. However, in the second season, Both Beny Ebeid fields received similar amounts to those received in the first season (Quantity4.87 and dose $0.97 \mathrm{Kg} / 100 \mathrm{~m}^{2}$ during summer and spring). Mansoura University field received medium amounts of nitrogen quantity (Quantity 3.12 and dose $0.62 \mathrm{Kg} / 100 \mathrm{~m}^{2}$ ) through five doses during summer and spring. Data of the second season also showed that ElShaab field received less nitrogen quantity (Quantity 2.27 and dose $0.75 \mathrm{Kg} / 100 \mathrm{~m}^{2}$ ) during summer and spring periods compared with the first season. Data also revealed that Mansoura field received the lowest nitrogen quantity among all five fields under study in both growth periods.

Table 3. Quantity of fertilizers applied to different fields throughout the two seasons.

\begin{tabular}{|c|c|c|c|c|c|c|}
\hline \multirow[t]{3}{*}{ Field } & \multicolumn{3}{|c|}{$\begin{array}{c}\text { (Nitrogen)(*Kg } \\
\left./ \neq=100 m^{2} / y r\right) \\
\text { Summer \& Spring }\end{array}$} & \multicolumn{3}{|c|}{$\begin{array}{c}\text { (Phosphorus) }\left({ }^{*} \mathrm{Kg}\right. \\
\left./ * 100 \mathrm{~m}^{2} / \mathrm{yr}\right) \\
\text { Fall \& Winter }\end{array}$} \\
\hline & \multicolumn{3}{|c|}{ First season } & & & \\
\hline & Number & Quantit & dose & Number & Quantit & Dose \\
\hline Beny Ebeid & 5 & $4.84^{\circ}$ & 0.97 & 2 & 1.40 & 0.70 \\
\hline $2^{\text {nd }}$ B. E. & 5 & 4.84 & 0.97 & 2 & 1.40 & 0.70 \\
\hline M.University & 5 & 3.12 & 0.62 & 2 & 0.69 & 0.34 \\
\hline Mansoura & 3 & 2.87 & 0.95 & 1 & 0.64 & 0.64 \\
\hline El-Shaab & 5 & 4.50 & 0.90 & 2 & 0.71 & 0.35 \\
\hline & & Seconc & seaso & & & \\
\hline Beny Ebeid & 5 & 4.84 & 0.97 & 2 & 1.40 & 0.70 \\
\hline $2^{\text {nd }}$ B. E. & 5 & 4.84 & 0.97 & 2 & 1.40 & 0.70 \\
\hline M.University & 5 & 3.12 & 0.62 & 2 & 0.69 & 0.34 \\
\hline Mansoura & 2 & 1.81 & 0.90 & 0 & 0.00 & 0.00 \\
\hline El-Shaab & 3 & 2.27 & 0.75 & 0 & 0.00 & 0.00 \\
\hline
\end{tabular}

* Kg of nitrogen or phosphorus fertilizer $* * 100 \mathrm{~m}^{2}$ of turfgrass

As for Phosphorus quantity applied during winter to the fields, data clearly showed that both Beny Ebeid fields received the highest Phosphorus quantity among all fields in both seasons (Quantity 1.40 and dose $0.70 \mathrm{Kg} / 100 \mathrm{~m}^{2}$ ), followed by El-Shaab field in first season (Quantity 0.71 and dose $0.35 \mathrm{Kg} / 100 \mathrm{~m}^{2}$ ). On the other hand, Mansoura University field received (Quantity 0.69 and dose 0.34 $\mathrm{Kg} / 100 \mathrm{~m}^{2}$ and Mansoura Field received (Quantity 0.64 and dose $0.64 \mathrm{Kg} / 100 \mathrm{~m}^{2}$ ) in the first season, El-Shaab field and Mansoura Field while received no P during the second season.

Table (4) showed color scale of grasses of the five fields during the three growth periods in the two seasons. Data showed that color scale was significantly the highest during summer (averaged 6.06 and 6.87), followed by spring (averaged 5.02 and 5.38), and was the lowest during winter (averaged 4.07 and 4.87) in the first and second seasons, respectively. In general, in the first season El Shaab field received the highest significant averaged color (averaged 5.67), followed by Mansoura University field (averaged 5.11) scale in all growth periods, On the other hand, Beny Ebeid fields (averaged 4.89). while Mansoura field had the lowest color value.in the second season, Mansoura University averaged best color scale in all growth periods, while Mansoura field had the lowest color value. El Shaab field and both Beny Ebeid fields, however, had very close color scales to that of Mansoura University field.

Table 4. Color scale in clippings of different fields throughout the two seasons.

\begin{tabular}{|c|c|c|c|c|}
\hline $\begin{array}{l}\text { Growth } \\
\text { period(B) } \\
\text { /field(A) }\end{array}$ & $\begin{array}{l}\text { Summer } \\
\text { (July - } \\
\text { Oct.) }\end{array}$ & $\begin{array}{c}\text { Fall \& } \\
\text { Winter } \\
(\text { Nov. - Feb.) }\end{array}$ & $\begin{array}{l}\text { Spring } 1 \\
\text { (Mar. - } \\
\text { June) }\end{array}$ & $\begin{array}{c}\text { Mean } \\
\text { of } \\
\text { (A) }\end{array}$ \\
\hline \multicolumn{5}{|c|}{ First season } \\
\hline Beny Ebeid & 6.33 & 3.67 & 4.67 & 4.89 \\
\hline $2^{\text {nd }}$ B. E. & 6.33 & 3.67 & 4.67 & 4.89 \\
\hline M.University & 6.00 & 4.33 & 5.00 & 5.11 \\
\hline Mansoura & 5.33 & 4.00 & 4.67 & 4.66 \\
\hline El-Shaab & 6.33 & 4.67 & 6.00 & 5.67 \\
\hline Mean of(B) & 6.06 & 4.07 & 5.02 & \\
\hline L.S.D. & $=0.76$ & $(B)=0.59$ & $9 \quad(\mathrm{AB})=$ & $=1.32$ \\
\hline \multicolumn{5}{|c|}{ Second season } \\
\hline Beny Ebeid & 7.00 & 4.67 & 5.33 & 5.67 \\
\hline $2^{\text {nd }}$ B. E. & 6.67 & 4.33 & 5.33 & 5.44 \\
\hline M.University & 7.00 & 5.67 & 6.67 & 6.44 \\
\hline Mansoura & 6.67 & 4.33 & 4.67 & 5.22 \\
\hline El-Shaab & 7.00 & 5.33 & 4.87 & 5.73 \\
\hline Mean of(B) & 6.87 & 4.87 & 5.38 & \\
\hline
\end{tabular}

$\begin{array}{lll}\text { L.S.D. } \quad(A)=0.49 & (\mathrm{~B})=0.38 \quad(\mathrm{AB})=0.86\end{array}$

Turf color: was visually evaluated and was scored on a scale of $1-$ 9 (where, 8-9= dark green, 6-7=green, 5-6=yellowish green, 3-4=greenish yellow, and 1-2=yellow or brown).

Table (5) showed the total chlorophyll content in clippings of grasses of the five fields during the three growth periods in the second season. Data showed that the highest chlorophyll content took place during summer $(1.19 \mathrm{mg})$, followed by spring $(0.78 \mathrm{mg})$, and while the lowest content $(0.46 \mathrm{mg})$ took place during winter months. Data of the table also showed that grass of Mansoura University field contained the highest average total chlorophyll content $(0.87 \mathrm{mg})$ followed by Beny Ebeid (0.84 mg) and El Shaab (0.82 mg) fields, while second Beny Ebeid and Mansoura fields had the lowest contents. The highest total chlorophyll content was that in clippings during summer in Beny Ebeid field (1.28 mg), followed by Mansoura University field $(1.27 \mathrm{mg})$, while the lowest was that of Mansoura field (1.08 mg). 
Table 5. Total chlorophyll in fresh clipping samples of the fives fields throughout the second season.

\begin{tabular}{|c|c|c|c|c|}
\hline \multirow[b]{2}{*}{$\begin{array}{l}\text { Growth } \\
\text { period(B) } \\
\text { /field(A) }\end{array}$} & \multicolumn{4}{|c|}{ Total chlorophyll (mg/g F. W.) } \\
\hline & $\begin{array}{l}\text { Summer } \\
\text { (July - } \\
\text { Oct.) }\end{array}$ & $\begin{array}{c}\text { Fall \& } \\
\text { Winter } \\
\text { (Nov. - Feb.) }\end{array}$ & $\begin{array}{l}\text { Spring } \\
\text { (Mar. - } \\
\text { June) }\end{array}$ & $\begin{array}{l}\text { Mean } \\
\text { of }(\mathbf{A})\end{array}$ \\
\hline Beny Ebeid & 1.28 & 0.43 & 0.81 & 0.84 \\
\hline $2^{\text {nd }}$ B. E. & 1.16 & 0.38 & 0.79 & 0.78 \\
\hline M.University & 1.27 & 0.53 & 0.84 & 0.87 \\
\hline Mansoura & 1.08 & 0.48 & 0.74 & 0.76 \\
\hline El-Shaab & 1.16 & 0.51 & 0.77 & 0.82 \\
\hline Mean of(B) & 1.19 & 0.46 & 0.78 & \\
\hline L.S.D. & $(A)=0 . C$ & $(B)=($ & $06 \quad(\mathrm{AB}$ & 13 \\
\hline
\end{tabular}

Table (6) showed N, P and $\mathrm{K}$ percentages in clippings of grasses of the five field's in the second season. It is obvious from the table that Beny Ebeid field clippings contained the highest percentages of the three elements, followed by the second Beny Ebeid field, while Mansoura University field ranked third. El Shaab field ranked fourth in order, while Mansoura field had the lowest percentages of the three elements among the five grass fields.

Figure (1) showed turfgrass quality of the five fields throughout the first season. The figure clearly showed that was the highest during early summer and late spring months, while was the lowest during winter months. The best quality values were those of Mansoura university and Beny Ebeid fields. Quality of Mansoura University field was maintained around 7 scale from July until September, then decreased to 6 from October to December, reached 4.5 value in January, and increased again starting from February to reach 7 value again by June. Beny Ebeid field showed similar trend and values like Mansoura University field and the only difference was that the quality values during October to December were at scale 5 . The lowest quality values among all fields were those of Mansoura field

Table 6. Major Elements (NPK) percentages in clipping samples of the fives fields in the second season.

\begin{tabular}{lccc}
\multicolumn{4}{c}{ samples of the fives fields in the second season. } \\
\hline Fields & $\mathbf{N} \%$ & $\mathbf{P \%}$ & $\mathbf{K \%}$ \\
\hline Beny Ebeid & 2.75 & 0.31 & 3.00 \\
2 $^{\text {nd }}$ B. E. & 2.68 & 0.30 & 2.94 \\
M.University & 2.238 & 0.26 & 2.52 \\
Mansoura & 2.133 & 0.21 & 2.38 \\
El-Shaab & 2.404 & 0.25 & 2.62 \\
L.S. D. & 0.08 & 0.01 & 0.09 \\
\hline
\end{tabular}

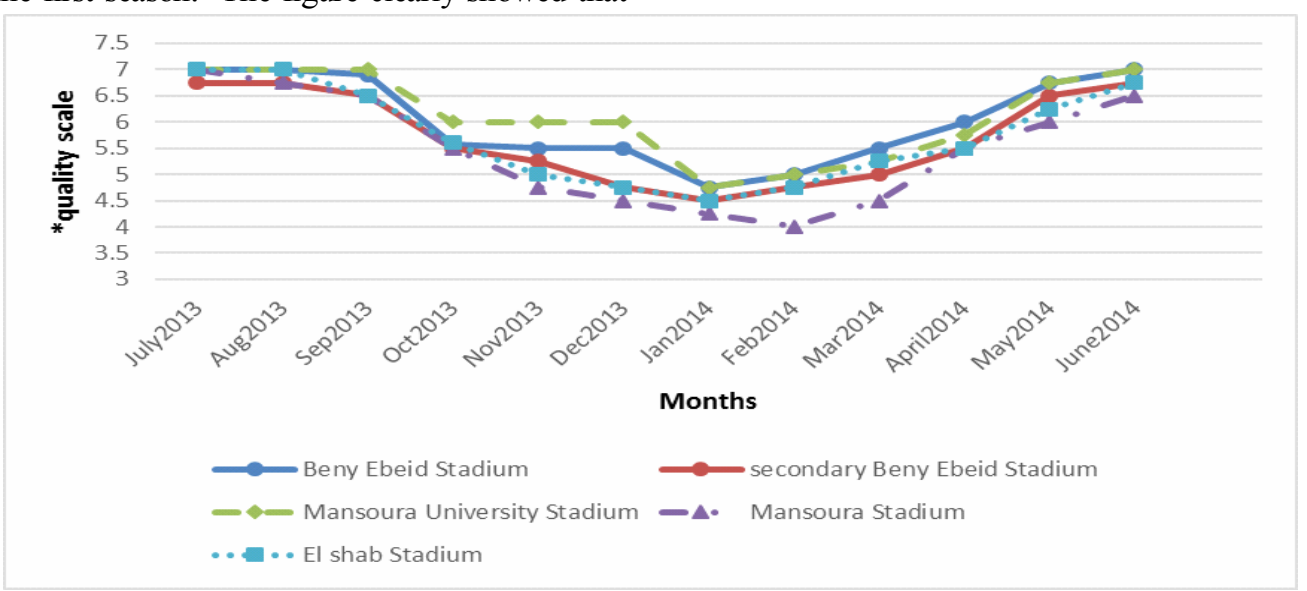

Figure 1. Turfgrass quality of the five fields throughout the first season.

"Turf quality: turf quality was visually scored according to Alshammary et al., (2004) on a scale of 1-9, based on density, uniformity and color, where $8-9=$ excellent ideal green, dense, and uniform turf, 6-7= good, 4-5= acceptable, 3-4= bad, and1-2= very bad or completely dead or dormant brown/yellowish colored turf. Any value below four was considered as unacceptable quality.

Figure (2) showed turfgrass quality of the five fields throughout the second season. The quality values followed similar trend as the first season. However, the best quality values were those of Mansoura University, Beny Ebeid and 2nd beny Ebeid fields. In the second season, however, the quality values of all fields during spring months (from March to June) were 7 and above until reached 8 by June in case of Mansoura University and Beny Ebeid fields. The figure also showed that the least quality values were those of Mansoura field.

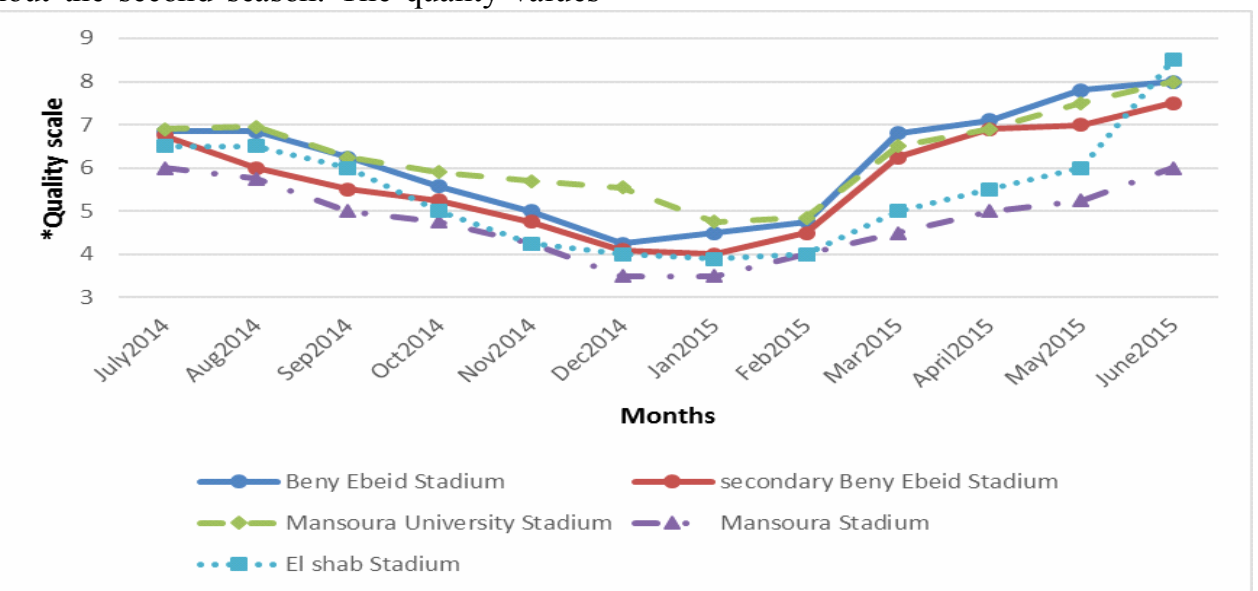

Figure 2. turfgrass quality of the five fields throughout the second season 
"Turf quality: turf quality was visually scored according to Alshammary et al., (2004) on a scale of $1-9$, based on density, uniformity and color, where 8-9 = excellent ideal green, dense, and uniform turf, 6-7= good, 4-5= acceptable, 3-4= bad, and1-2= very bad or completely dead or dormant brown/yellowish colored turf. Any value below four was considered as unacceptable quality.

\section{Discussion}

The results showed that nitrogen fertilization affected color and quality of the turfs of the five fields and chlorophyll and nitrogen contents of their leaves in different ways. Nitrogen is an essential constituent of chlorophyll, amino acids, nucleic acids, enzymes and vitamins, and thus, color and quality of a turf is directly correlated with the level of nitrogen nutrition. Accordingly, nitrogen is usually applied in the greatest amounts of any of the nutrient elements (Beard, 1973).

The results showed that there was a relationship between number of nitrogen fertilizer applications, dose and total nitrogen quantity applied to each field in one hand and color and quality on the other. The lowest amount of nitrogen added to Mansoura Stadium field led to the lowest color and quality of the turf among all fields. On the other hand, although higher nitrogen amount added in case of both Beny Ebeid fields increased nitrogen content in the leaves, a lesser nitrogen amount led to a better color and quality as the case in Mansoura University field. The turf used in all fields is Paspalum (Paspalum vaginatum Sw.) which was reported by Trenholm and Unruh (2003) to be very responsive to nitrogen, therefore, when using of quickrelease nitrogen fertilizer, the application rate should be limited to $250 \mathrm{~g} \mathrm{~N} / 100 \mathrm{~m} 2$ at any single time, and an annual rate of $1.6 \mathrm{Kg} / 100 \mathrm{~m} 2$. Also, according to Phillip Jennings Turf Farms (2009), the N recommendation for Seashore Paspalum is low at approximately $1.46 \mathrm{Kg} \mathrm{N} / 100 \mathrm{~m} 2$ / year.

The results also showed that increasing number of $\mathrm{N}$ applications had a positive effect on color and quality of the turf in addition to its chlorophyll content. For example, in the first season, El-Shaab field received five nitrogen fertilizer applications and had a better color than Mansoura University, probably because it received slightly higher amount of nitrogen than Mansoura University. In the second season, however, when nitrogen was applied three times only to El-Shaab field, the lawn had less color than Mansoura University which received five $\mathrm{N}$ applications. Furthermore, in ElShaab field, the reduced number of applications associated with lower amount of nitrogen, in the second season, led to lower chlorophyll and nitrogen contents in the leaves and to less color and quality of the turf. The results also showed that Mansoura Stadium field received larger dose than those used for either Mansoura University or El-Shaab fields but the least number of applications, and had the least color and quality among all fields. Thus, one can conclude that the lesser number of applications associated with large amount of nitrogen would lead to reduced color and quality, and the more number of applications associated with small dose of nitrogen each time would lead to a better color and quality. These results go along with Beard (1973) and
Trenholm and Unruh (2003) who reported that fertilizer should be applied to seashore paspalum using small doses on regular bases throughout the growing season.

It is clear that a balance between number of nitrogen fertilizer applications, dose, and total nitrogen should be maintained in order to achieve better color and quality of the turfgrass. In general, Mansoura University field showed better color and quality in this study because it received reasonable doses (number and quantity) compared with all fields, and it seems that it is important to study if increasing its dose a bit higher from which was used might lead to better color and quality.

As for phosphorus, the results showed that more phosphorus fertilization to some fields in the first season was not associated with better color and quality compared with those received less phosphorus, probably because the low phosphorus fertilization in some fields was enough for the turf needs. Beard (1973) and Beard et al., (1991) indicated that phosphorus fertilizer should be applied based solely on soil test recommendations, since when deficiencies are not detected, there is no need for phosphorus fertilization. However, in the second season, the lack of adding phosphorus to El-Shaab and Mansoura Stadium fields reduced their quality in addition to reducing their phosphorus content of the leaves compared with the first season. These results strongly support the need of adding phosphorus to the fields (depending on soil testing). Phosphorus is a component of many cell structures such as phospholipids, nucleotides, coenzymes, sugar phosphates, and nucleic acids, and all metabolic processes that use ADP or ATP for energy transformation require phosphorus (Taiz, 2002). In turfgrasses, $P$ shortens the establishment stage and produces more vigorous rooting, which enhance turfgrass cold/heat tolerance, increase drought recovery and water use efficiency (Carrow et al., 2001). On the other hand, the increase in phosphorus fertilization in Beny Ebeid fields did not lead to increasing the turf quality over that of Mansoura University field which received less phosphorus fertilization. These results strongly support the need of adding phosphorus but to a much lesser degree than the need of nitrogen. Nitrogen fertilization also played an important role to increase the availability phosphorus to the plant (Gilbert et al., 1999; Wang et al., 2007). Aamlid et al., (2013) reported that phosphorus is normally bound in the soil in the form of an insoluble salt, and addition of nitrogen fertilizer increased $\mathrm{P}$ availability.

\section{CONCLUSION}

Paspalum turfgrass used in all the five fields is characterized of being strong growth turfgrass, it need nitrogen fertilization as other turfgrasses, but its nitrogen requirements are not very high. According to the data collected from the maintenance programs applied for these fields, which we have no control over them, we found that they need to increase the number of applications with reasonable low doses (as those applied to Mansoura University field) in order to have better fields. Phosphorus fertilization is also needed during 
winter based on soil testing, since when phosphorus was not added to El-Shaab and Mansoura Stadium fields, their color and quality was greatly reduced. Based on this analysis, Mansoura university fertilization program was better than other programs and led to a betterquality field.

\section{REFERENCES}

Aamlid, T.S., T.E. Andersen, A. Kvalbein, T. Pettersen, A.M.D. Jensen \& P. Rasmussen (2013) Use of compost in the root zone or in the topdressing sand on red fescue greens. Results from the period August 2011 - November 2012. Bioforsk Report 8(168): 1-37.

Alshammary, S.F.; Y.L. Qian and. S.J. Wallner. (2004). Growth response of four turfgrass species to salinity. Agricultural Water Management, 66: 97-111.

Beard, J.B. (1973). Turfgrass: Science and Culture. Prentice Hall, New York, USA.

Beard, J.B., S.I. Sifers, and M.H. Hall. (1991). Cultural strategies for seashore paspalum. Grounds Maintenance, August 1991, p. 32, 62.

Carrow, R.N., D. V. Waddington and P. E. Rieke (2001). Turfgrass soil fertility and chemical problems: Assessment and management. Pub. Wiley, Hoboken, N.J., USA.

Cockerham S.T., V.A. Gibeault, and D.B. Silva (2004). Establishing and Maintaining the Natural Turf Athletic Field: Publication 21617. University of California, ANR Communications, Oakland, CA, USA.

Gomez. and A.A. Gomez (1984): Statistical Procedures. Agric. Res., $2^{\text {nd }}$ Ed. John Wiley and Sons, Inc, New York, USA.

Jackson M.L. (1960). Soil Chemical Analysis. Prentic-Hall, Inc., Engle Wood Cliffs. N.J., USA.
Kock, F.C. and T.L. Mc-Meekin, (1962). A new direct nesslerization major element's method and a modification of the Nessler- folio reagent. J. Amer. Chem. Soc., 46: 2066.

Mackinney G. Zscheile, F. P., and Comar, C. L., Bot. (1941). Absorption of light by chlorophyll solutions Gaz., 102,463 .

Murphy, J., and Riley, J.P., 1962, A modified single-solution method for the determination of phosphorus in natural waters: Analytica Chimica Acta, v. 27, p. 31-36.

Phillip Jennings Turf farms. (2009). Sea Isle Supreme 2000 Paspalum. Retrieved May 22, 2009 from http:/www.sodfather.com/turf-grass /seaisle - 2000paspalum. asp

Taiz, L., E. Zeiger. (2002). Plant Physiology. Sinauer Associates, Inc., Sunderland, MA.

Trenholm, L.E. and J. B. Unruh (2003). Seashore Paspalum Management for Home Lawn Use in Florida. Environmental Horticulture Department, Florida Cooperative Extension Service, Institute of Food and Agricultural Sciences, University of Florida. document is ENH 897, pp. 1-4. http://ufdcimages.uflib.ufl.edu/ IR/00/00/17/53/00001/EP15300.pdf

Turner, T. R. and Hummel, N. W. (1992). Nutritional requirements and fertilization pp.385-439.In Waddington et al. (eds.) Turfgrass, Agronomy Monograph No.32. ASA, CSSA, and SSSJ. Madison, WI.

Villwock M., E. Meyer, J.Powell, A. Fouty, and R. Haut. (2009). Football Playing Surface Components May Affect Lower Extremity Injury Risk. Proceedings of the 11th ASME Summer Bioengineering Conference, P: 253-254.

Wang, Y.P., B.Z. Houlton, and C.B. Field. 2007. A model of biogeochemical cycles of carbon, nitrogen, and phosphorus including symbiotic nitrogen fixation and phosphatase production. Global Biogeochemical Cycles. Vol. 21: 1018-1029.

Wilde, S.A., R.B. Corey, J.G. Lyer, and G.K.Voigt. (1985). Soil and plant Publishing Co., New Delhi, India.

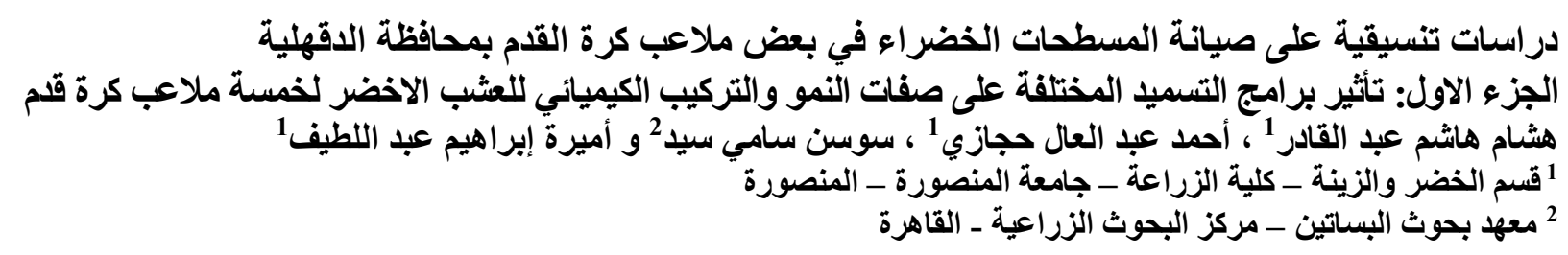

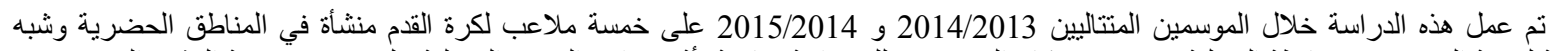

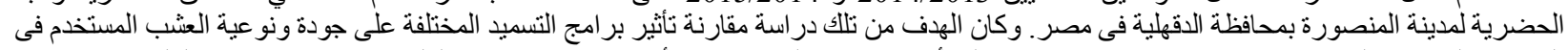

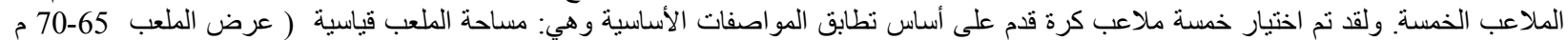

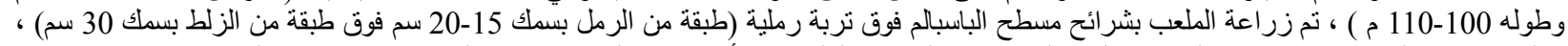

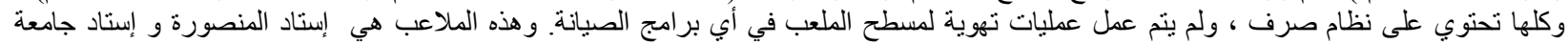

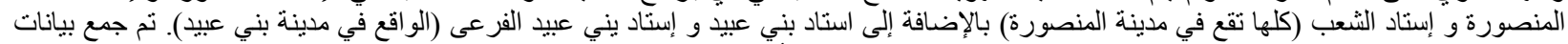

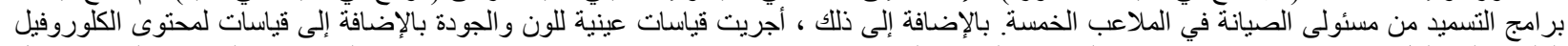

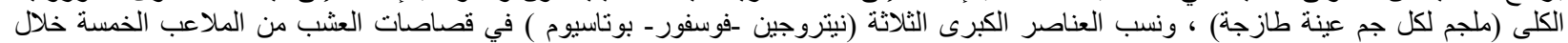

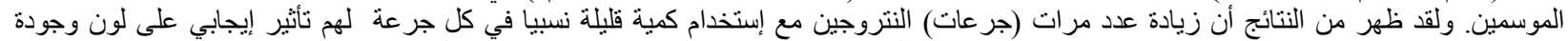

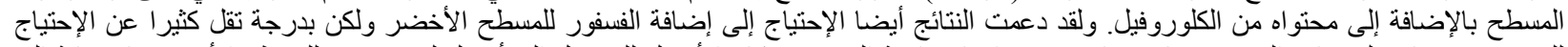

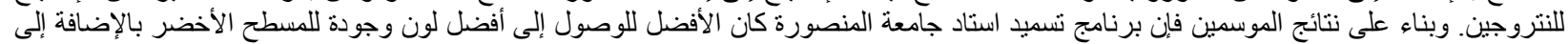

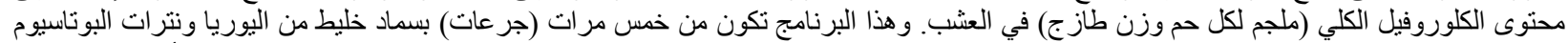

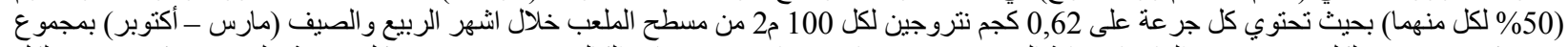

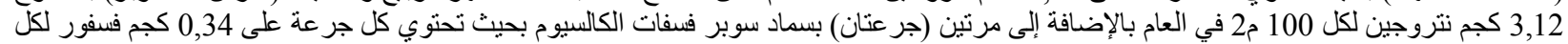

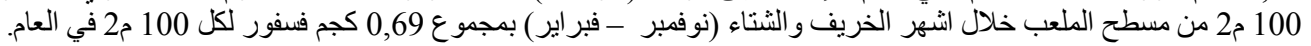

